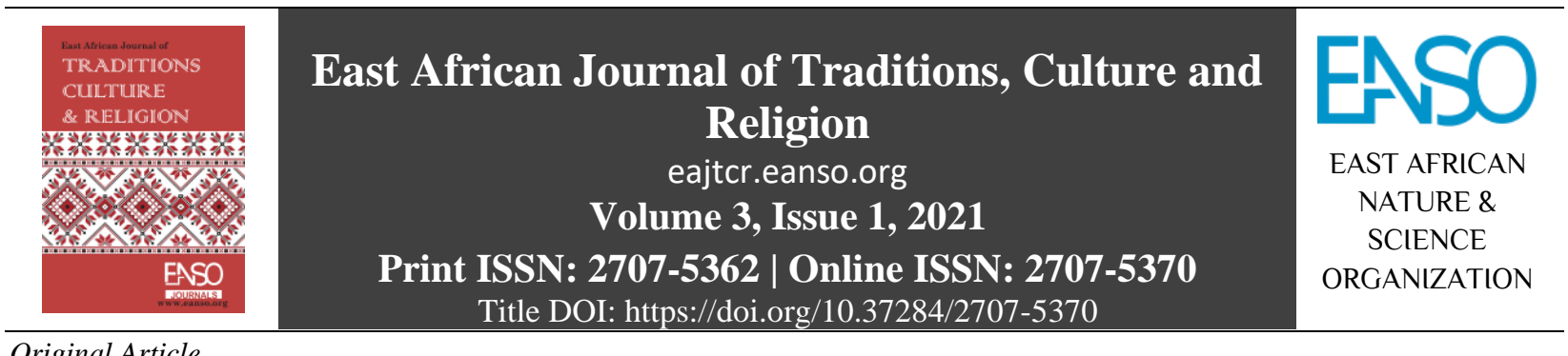

Original Article

\title{
The Meaning of Speaking in Tongues: A Practical Strategy for the 21st Century Church.
}

\author{
John Sirengo \\ ${ }^{1}$ Friends Theological College-Kaimosi, P. O. Box 9-50309, Tiriki, Kenya \\ Author Correspondence Email: Sirengojohn71@gmail.com.
}

Article DOI: https://doi.org/10.37284/eajtcr.3.2.354

\section{Date Published: ABSTRACT}

05 July 2021 The meaning of speaking in tongues portrays a language that challenges the church in its interpretation in matters of spiritual gifts from God. This article focuses on the

Keywords: Old and New Testament perspectives on tongues; tongues reveal God's judgment, promises, fulfilment and its negative usages such as selfishness, jealousy, and

Speaking, discouragement. This is mostly for those who do not speak the language. On its Language, positive side it looks at it as an initial sign of baptism in the spirit in which the Dialect, Pentecostals and charismatic movements put their emphasis on the faith and Gift, edification of the individual and prophecy to the entire church. Church history Gift, provides the understanding of the use of tongues particularly in reference to early Sign, church fathers, such as Eusebius, Irenaeus, Dean Ferrar, Chrysostom Bishop of Utterance, Constantinople, and Augustine of Hippo and briefly on the reformation period. It Spirit. concludes by proposing the practical strategies for discovering the gift of tongues, through workshops on spiritual gifts, small group discussions, gift discovery group and its application in the church and individual.

\section{APA CITATION}

Sirengo, J. (2021). The Meaning of Speaking in Tongues: A Practical Strategy for the 21st Century Church. East African Journal of Traditions, Culture and Religion, 3(1), 11-18. https://doi.org/10.37284/eajtcr.3.1.354

\section{CHICAGO CITATION}

Sirengo, John. 2021. "The Meaning of Speaking in Tongues: A Practical Strategy for the 21st Century Church.”. East African Journal of Traditions, Culture and Religion 3 (1), 11-18. https://doi.org/10.37284/eajtcr.3.1.354.

\section{HARVARD CITATION}

Sirengo, J. (2021) "The Meaning of Speaking in Tongues: A Practical Strategy for the 21st Century Church.", East African Journal of Traditions, Culture and Religion, 3(1), pp. 11-18. doi: 10.37284/eajtcr 3.1.354.

\section{IEEE CITATION}

J. Sirengo, "The Meaning of Speaking in Tongues: A Practical Strategy for the 21st Century Church.”, EAJTCR, vol. 3, no. 1, pp. 11-18 Jul. 2021.

11 | This work is licensed under a Creative Commons Attribution 4.0 International License. 


\section{MLA CITATION}

Sirengo, John. "The Meaning of Speaking in Tongues: A Practical Strategy for the 21st Century Church.” East African Journal of Traditions, Culture and Religion, Vol. 3, no. 1, Jul. 2021, pp. 11-18, doi:10.37284/eajtcr.3.1.354.

\section{INTRODUCTION}

"Speaking in Tongues" is generally referred to as one of the gifts of the Holy Spirit mentioned in 1 Corinthians $12: 10$ "...to another the ability to speak in different kinds of tongues" (NIV). Other scriptural references may include the following: (1 Cor 12: 10, 28; 13: 1; 14: 4, 5, 22; Mark 16: 17; Acts 2: 2-13; 10: 44-46; and 19: 1-7; Rom 8: 26, 27; Eph 6: 18). However, Michael Green in his book I believe in the Holy Spirit defines tongues as "The ability to speak in the language that the speaker has not learned, that he does not understand, and that is incomprehensible to the hearer" (Green, 2004, p. 210). Green hesitates in mentioning the word "language" to him is not the human language but the "Holy Spirit language designed to enable both men and angels to worship God in greater depth and with greater release in their inner being" (Green, 2004, p. 210).

On the other hand, Wayne Grudem in his book Systematic Theology, defines the gift of speaking in tongues as, "prayer or praise spoken in syllables not understood by the speaker" (Grudem, 1994, p. 1070). The element of praise in speaking in a tongue is illustrated in what the apostle Paul had spoken "If I pray in a tongue, my spirit prays, but my mind is unfruitful" (1 Cor. 14: 14 NIV). The mind in this case was to be involved in the prayer so that the idea of the interpreter could come in or the same person speaking in tongues could do the interpretation.

More emphasis on the definition of the gift of tongues has been contributed by C. Peter Wagner Who says that it "is the special ability that God gives to certain members of the body of Christ (A) to speak to God in a language they have never learned and /or (B) to receive and communicate an immediate message utterance in a language they have never learned" (Wagner, 2007, p. 234). This definition contributes to two ideas in the sense that some members in the church do not possess certain gifts of the Holy Spirit. While on the other side God communicates his message through man's utterances in unlearned languages. In addition, Wagner categorizes the gift of tongues into two varieties that is "Private tongues and Public tongues" (Wagner, 2007, p. 234). The two varieties are from Paul's emphasis (1 Cor 14: 27, 28). Private tongues are what Wagner refers to it as "Prayer language" (Wagner, 2007, p. 234). There should be no accompanying of the gift of interpretation and this concerns the individual prayer focused on God. Public speaking in tongues involves the interpretation of the utterances with the same person or a different person. To bring the point back home, Wagner is right when he says that, "The gift of interpretation is the special ability that God gives to certain members of the body of Christ to make known in the vernacular the message of one who speaks in tongues- public tongues are equivalent to prophecy" (Wagner, 2007, p. 234). What to be interpreted is rather prophecy nothing else.

Consequently, Siegfried Grossman argues that "The Greek word glossa means "tongue" and "language" (Grossman, 2008, p. 77). The two words tongue and language as they have been translated have different meanings to different people. For this reason, Grossman asserts that "The translation "speaking in tongues" is confusing it gives the impression of unarticulated babbling-this obviously does not fit the meaning of the Greek term as it is used in the New Testament, speaking in other languages is a normal practice to many people in different dialects" (Grossman, 2008, p. 77). The will of God is to be manifested in any object that he wishes. "This Charisma is subject to the will; whoever has this gift can start and stop whenever he wishes, he can speak slowly or quickly, loudly or softly" (Grossman, 2008, p. 77). The person who does the interpretation should also possess the ability to speak in tongues.

Another New Testament commentator, Charles V. Bryant has described the phrase "gift of tongues" for the word, glossolalia, "which combines two words: lalia, signifying any utterance of sound, whether intelligent or un intelligent and glossa, meaning literally "tongue," but implying "language." Glossalalia nowhere appears in the New Testament; usually, the Greek word translated "tongue(s), is glossa" (Bryant, 1997, p. 116). Tongues, therefore, can refer to a heavenly dialect whether known or unknown. Having understood the Greek meaning of 
the word tongues, Bryant therefore defines it as, "The special ability or power God gives to some members of the body to communicate in a way that may or resemble a known or acceptable language for the purpose of transcending the limitations of normal speech to minister to, for, and through the body of Christ" (Bryant, 1997, p. 116).

\section{THE OLD TESTAMENT PERSPECTIVES ON TONGUES}

\section{A Sign of Judgment}

The positive purpose of tongues in the Old Testament was used to rebuke or was used as a sign of judgment to the unbelievers not for believers. As compared to the gift of prophecy, was used for the believers. The apostle Paul says that "Tongues, then, are a sign not for believers but for unbelievers; prophecy, however, is for believers, not for unbelievers" (1 Cor 14: 22 NIV). The apostle Paul quotes from the prophet Isaiah 28: 11-12, to illustrate his point. "Very well then, with foreign lips and strange tongues God will speak to this people, to whom he said, this is the place of reposebut they would not listen."

Following the history of the Israelites, the Northern 10 tribes of Israel, when they had been taken off into captivity by the Assyrians, the Prophet Isaiah warns the remaining two Southern tribes of Judah and Benjamin, that the same judgment was waiting for them unless they repented. In the Old Testament times, to be addressed by God in a non- Hebrew language was used as a symbol of judgment or rebuke to the Hebrew mind. The Prophet Moses, Jeremiah, and Isaiah had the same fashion concerning this message. "The LORD will bring a nation against you from far away, from the ends of the earth, like an eagle swooping down, a nation whose language you will not understand" (Deut 28: 49, NIV). In addition, the Prophet Jeremiah 5: 15, states "O house of Israel, declares the LORD, I am bringing a distant nation against you-an ancient and enduring nation, a people whose language you do not know, whose speech you do not understand." However, tongues were categorically used as a sign to unbelieving Israel as the coming judgment from God in response to repentance for the forgiveness of sins.

\section{THE NEW TESTAMENT PERSPECTIVES ON TONGUES}

\section{A. A Sign of Promise}

Reading from the synoptic gospels particularly the gospel according to Mark, tongues is being mentioned as a sign promised from Jesus Christ to his disciples for the coming ministry. "And these signs will accompany those who believe: In my name, they will drive out demons; they will speak in new tongues" (Mark 16: 17 NIV). In addition, he says that "The promise is for you and your children and for all who are far off for all whom the Lord our God will call" (Acts 2:39 NIV). The apostle Peter had mentioned this before those who had spoken in tongues and the onlookers at Pentecost day in the book of Acts.

\section{B. A Sign of Fulfilment}

A sign of fulfilment is illustrated by the apostle Peter who reaffirmed this idea on the day of Pentecost. "All of them were filled with the Holy Spirit and began to speak in other tongues as the Spirit enabled them" (Acts 2: 4 NIV). As a fulfilment from the prophets, the apostle Peter continued to remind them of the way Jesus had been crucified in their hands, speaking in tongues was a warning to the coming judgment to them. "With many other words he warned them; and he pleaded with them, Save yourselves from this corrupt generation" (Acts 2: 40 NIV).

Tongues, as a gift is clearly illustrated in the three accounts in the book of Acts. First, it had occurred in the city of Jerusalem on Pentecost day. The Apostle Paul says, "All of them were filled with the Holy Spirit and began to speak in other tongues as the Spirit enabled them" (Acts 2: 4 NIV). As a historical fact, speaking in tongues was a fulfilment of the prophecy of Joel 28: 30. Secondly, tongues had also occurred in Caesarea Philippi when the apostle Peter had preached to the Gentiles, the Holy Spirit fell on them and they spoke in tongues, at the same time the Jews of the circumcision were amazed. "For they heard them speaking in tongues and praising God" (Acts 10: 46 NIV). Thirdly, in Ephesus, the Apostle Paul meets 12 men and, in their conversation, it was discovered they were the apostles of John the Baptist. After being confirmed 
not having received the Spirit when they were baptized by John the Baptist, they were baptized in the name of Jesus Christ, and "when Paul placed his hands on them, the Holy Spirit came on them, and they spoke in tongues and prophesied" (Acts 19: 6 NIV).

\section{THE NEGATIVE MEANING OF TONGUES}

\section{A. Selfishness}

The purpose of tongues was not for the edification of the church as the apostle had mentioned, that " $\mathrm{He}$ who speaks in a tongue edifies himself, but he who prophesies edifies the church...But in the church I would rather speak five intelligible words to instruct others than ten thousand words in a tongue" (1 Cor. 14: 4, 19 NIV). Here, Paul meant that there was no personal edification that could be termed as selfish. The apostle Paul did not wish people to act in the unscriptural way of the gift of tongues. The same idea applies in the present-day church that when one speaks in tongues, it demonstrates as a sign of salvation. Such false concepts were totally refuted by the apostle Paul in the early church, "For we were all baptized by one Spirit into one body-whether Jews or Greeks, slave or free and we were all given the one Spirit to drink" (1 Cor. 12: 13 NIV). The gift of tongues according to Paul was to build the body of Christ, the church, not the selfish manifestations of an individual.

\section{B. Discouragement and Jealousy}

Discouragement and Jealousy are some of the facets that the members of the church who do not speak in tongues can easily be considered as victims. It has been recognized by Bridge and Phyphers in 1 Corinthians 12 that "When gifts are exercised within a church or fellowship, some Christians might easily become discouraged because they do not exhibit the same gifts they see in others, in their discouragement they might become jealous and resent their apparent poverty where gifts are concerned" (Bridge \& Phyphers, 1999, p. 12-13).

\section{THE POSITIVE MEANING OF TONGUES}

\section{A. The Initial Sign of Baptism in the Spirit}

The Baptism of the Holy Spirit accompanying the evidence of speaking in tongues as a sign is highly emphasized by the Pentecostals and the Charismatic movements. The idea is not only propagated by the two movements, but the bible also affirms it. Tongues as a sign, Craig S. Keener asserts that "Most Pentecostals and many Independent Charismatics; however, see it as the initial physical sign of baptism in the Holy Spirit" (Keener, 2001, p. 173). It is affirmed biblically especially in Acts of the Apostles in chapter two indicating the initial sign of baptism in the Spirit. In this incident, the onlookers questioned the meaning of speaking in tongues. "Amazed and perplexed, they asked one another, "What does this mean?" (Acts 2: 12 NIV). In verse 13 others suggested as having taken a lot of wine and therefore they were drunk. When Peter stood quoting from the prophet Joel, he says:

No, this is what was spoken by the prophet Joel: In the last days, God says, I will pour out my Spirit on all people. Your sons and daughters will prophesy, your young men will see visions, your old men will dream dreams. Even on my servants, both men and women, I will pour out my Spirit in those days, and they will prophesy. I will show wanders in the heaven above and signs on the earth below, blood and fire and billows of smoke (Acts 2: 16-19 NIV).

If the Prophet Joel's prophecy was a fulfilment, and indeed it was, then the time for salvation was also ripe. Therefore, the apostle Peter seeing tongues as a sign was clear evidence of the coming of the Holy Spirit as empowerment for the whole all believers. Thus, Acts 2, acted as a model in which the Spirit had empowered the church. However, the idea of the spirit is also supported by Keener in the sense that "In Acts 10: 46-47, (they received the Spirit the same way we did). The spirit accompanies prophecy as evidence of prophetic empowerment in Acts 19: 6" (Keener, 2001, p. 177). This practice is further supported by the Pentecostals and the Charismatic movements.

The Pentecostals and Charismatics movements teach three distinctions or types of speaking in 
tongues: 1. Tongues as a supernatural outpouring and sign to unbelievers (Acts 2: 11), 2. Tongues for the strengthening of the church requires an interpretation (1 Cor. 14: 27), 3. Tongues as a private prayer language (Rom. 8: 26) (Strauss, 2004). But elsewhere in the bible especially the events in the book of Acts 8 and 9, the speaking in tongues is not seen, the only thing mentioned is the receiving of the Holy Spirit when they had laid hands on them. The other bible references that the Pentecostals use are: "Mark 16: 17; Acts 2: 4, 11; Acts 10: 46; Acts 19: 6; 1 Cor. 8: 5-29; 1 Cor. 12: 10, 28, 30; 1 Cor. 13: 1, 8" (Strauss, 2004).

\section{B. To Reveal the Spiritual Truth}

When 1 Corinthians 14 was written there was no proper information concerning the biblical truths about tongues, however, the reason for having tongues being spoken was at least to reveal the needed spiritual truths prior to the completion of the writing of the New Testament. When one speaks in a known tongue it may assist all the people. While speaking in tongues helps no one in the church apart from edifying oneself, then there is no need for church fellowship. The tongue when compared to a musical instrument portrays nothing apart from being heard and distinctly understood. "Even in the case of lifeless things that make sounds, such as the flute or harp, how will anyone know what tune is being played unless there is a distinction in the notes?" (1 Cor 14: 7 NIV). Tongues needed interpretation, the apostle Paul had once spoken in tongues more than other people as he claims, "I thank God that I speak in tongues more than all of you" (1 Cor. 14: 18 NIV). The apostle Paul is seen no more giving encouragements or forbidding the speaking in tongues in his missionary trips or testimonies. Here he notes, "Therefore, my brothers, be eager to prophesy, and do not forbid speaking in tongues" (1 Cor. 14: 39 NIV). However, in his realization, during those days, the people had not possessed the gifts in full. "Do all have gifs of healing? Do all speak in tongues? Do all interpret?" (1 Cor. 12: 30 NIV).

\section{Speaking to God in Prayer}

A prayer of a person speaking to God in the spirit is mentioned by the apostle Paul when he says, "For anyone who speaks in a tongue does not speak to men but to God. Indeed, no one understands him; he utters mysteries with his spirit" (1 Cor. 14: 2 NIV). Here, Paul means that the purpose of the gift of tongues has a new dimension in a person's prayer life. This calls for freedom of communing with God in the spirit. God alone understands the spiritual prayer life full of mysteries in tongues.

\section{Unknown Depth of Praise to God.}

In the book of Acts of the Apostles, we find a major illustration in the house of Cornelius when the apostle Peter was speaking, the Gentiles spoke in tongues and they glorified God. "For they heard them speaking in tongues and praising God" (Acts 10: 46 NIV). Michael Green supports this idea by saying that "...it is an undeniable fact that when people receive this gift of tongues, they find themselves free to praise and thank and adore and glorify their heavenly Father as never before" (Green, 2004, p. 212). In the present church, the adherents do much praise and worship as they climax speaking in tongues for the edification with God, no one understands what God meant to them. Rather, it is an illustration of God's Spirit at work in the Individual.

\section{E. Edification of the Individual}

It is a true fact that the apostle Paul did not deny that speaking in tongues does not edify the individual but it does. "He who speaks in a tongue edifies himself, but he who prophesies edifies the church" (1 Cor. 14: 4 NIV). In this verse Paul contrasts with the two gifts, that is; the gift of tongues for the edification of an individual and prophecy for the edification of the church. Michael Green argues that "It is one of the ways of growing in the Christian life for those who have been given the gift" (Green, $2004,213)$. Tongues were given the same way as other tongues were given for the profit of all. "Now to each one the manifestation of the Spirit is given for the common good" (1 Cor. 12: 7). However, the thing is that the gift of tongues allows an individual to pray even without the understanding of the mind, but communication with God is complete.

On the other hand, the idea of the message in tongues to be interpreted is clearly affirmed in the bible. God is nowhere gives the direct message to his people through speaking in tongues. Kenneth 
Cain in his book, Gifts of the Holy Spirit, identifies two events in the New Testament which illustrates that:

On the day of Pentecost those who heard the disciples speaking in tongues heard them speaking of "the mighty works of God" (Acts 2:11). And at Caesarea during the so-called Gentile Pentecost, those speaking in tongues were heard "extolling God" (Acts 10: 46). In both cases the speaking in tongues consisted of praise and thanksgiving directed upward to God, not outward to man (Kenneth, 2009, p. 103).

However, it is notified, therefore, that the three elements, the prayer, the praise, thanksgiving are utterances towards the almighty God. Whenever the interpretation is done it should be the edification of the individual, not the church.

\section{CHURCH HISTORY ON THE MEANING OF TONGUES}

\section{A. The Early Church Fathers}

\section{a. Eusebius}

Approximately in AD100, Eusebius a church historian is quoted by writing to the preaching evangelists, he says, "Of those that flourished in these times, Quadratus is said to have been distinguished for this prophetical gift...the Holy Spirit also wrought many wonders as yet through them, so that as the Gospel was heard, men in crowds voluntarily and eagerly embraced the true faith with their whole minds" (Conn, n.d). The use of spiritual gifts seems to have been put in the forefront for the ministry. Quadratus is seen as a model that had put into practice the functions of the gifts of the Holy Spirit.

\section{b. Irenaeus}

Irenaeus is said to have been a student of Polycarp and Polycarp being a disciple of John the apostle, in this succession Irenaeus as a church father had commented on those who had used the spiritual gifts in their ministry for in which they had achievements. In his book, it is written, "In like manner do we also hear many brethren in the church who possess prophetic gifts, and who through the Spirit speak all kinds of languages, and bring to light, for the general benefit, the hidden things of men and declare the mysteries of God, who also the apostles term spiritual" (Conn, n.d).

\section{c. Dean Ferrar}

Following the testimonies of those who had written about the early Martyrs approximately AD 300, Dean Ferrar, (Darkness to Dawn), writes, "Even for the minutest allusions and particulars I have contemporary authority" (Conn, n.d). Thus, the singing and speaking in unknown tongues were heard from the persecuted Christians. The practice had continued after the succession of the apostles.

\section{d. Chrysostom Bishop of Constantinople}

Chrysostom Bishop of Constantinople, approximately AD 390, asserts:

"Whoever was baptised in apostolic days, he straightway spoke with tongues, for since on their coming over from idols, without any clear knowledge or training in the Scriptures, they at once received the Spirit, not that they saw the Spirit, for He is invisible, but God's grace bestowed some sensible proof of His energy, and one straightway spoke in the Persian language, another in the Roman, another in the Indian, another in some other tongues, and this made manifest to them that were without that it was the Spirit in the very person speaking. Wherefore the apostle calls it the manifestation of the Spirit which is given to every man to profit withal" (Conn, n.d).

\section{e. Augustine of Hippo}

Augustine, Bishop of Hippo, Approximately AD. 400. Was the Father of the Latin Church and he was considered by historians as being the greatest among other Church Fathers. In his observations concerning the speaking in tongues, he says, "We still do what the apostles did when they laid hands on the Samaritans and called down the Holy Spirit on them on the laying-on of hands. It is expected that converts should speak with new tongues" (Conn, n.d). During this time, the Samaritans did not receive the Holy Spirit during their baptism. It took place later when the apostle Peter had laid hands on them but the incident of speaking in tongues was not

16 This work is licensed under a Creative Commons Attribution 4.0 International License. 
mentioned, probably, Augustine believes that speaking in tongues is a requirement after baptism.

\section{B. The Reformation}

During the Reformation in the $16^{\text {th }}$ Century church, we see some of the reformers refuting the speaking in tongues as compared to the early church fathers who testified the evidence of speaking in tongues. Keener quotes Jonathan Edwards as one who "warned of Spiritual counterfeits during genuine times of revival, and William Seymour argued that one who focused on signs more than on God and his holiness would get a counterfeit" (Keener, 2001, p. 125). The understandings differed but the true fact is that the evidence of the speaking in tongues was happening. On the other side focusing on the founders of the Methodist movement, the two brothers, John Wesley and Charles Wesley had some contributions towards tongues-speaking.

Keener observes that "Charles Wesley accepted revelations, prophecies, healings and so forth among his followers, but he emphasized that the true evidence of the Spirit was maturation toward Christian perfection" (Keener, 2001, p. 182). It seems probable that the two brothers did not teach or support the gift of speaking in tongues since their focus was limited to the three gifts mentioned above. Keener's research has provided with us information up to the twentieth-century missionaries coming to India. During this time, he mentions "Pandita Ramabai, the leading figure in a major early-twentieth-century outpouring of the Spirit in India, stressed that while tongues were one sign of baptism in the Spirit, the essential and inevitable sign was love" (Keener, 2001, p. 183).

\section{PRACTICAL STRATEGIES FOR DISCOVERING THE GIFT}

\section{A. A Workshop on Spiritual Gifts}

A primary purpose of the church to help solve the problems of the meaning of speaking in tongues is to have a workshop on Spiritual Gifts. The objective of the workshop is to help the church members to discover their Gift(s), through the bible-based teachings, an open forum for questions and opinions, reflections, sermons and sharing experiences. Thereafter leading them into practical ministry. Practicing what one has discovered for the edification of the Church.

\section{B. Small Group Discussions}

Small groups or cell groups are an avenue for teaching Church members to learn to serve others. A person learns how to pray for him/or herself and intercedes for the needs of others. For example, they learn how to know the ability they have for serving the church. Charles V. Bryant is sure when he says, "We learn from studying the New Testament that in small groups, such as with Jesus' disciples, and not in large crowds before which he preached, the foundation of the serving Church was laid" (Bryant, 1997, p. 154). The social relationship is developed resulting to love for each other.

\section{Gift Discovery Group}

The gift discovery group, it calls for the wholeness of the person in the relationship to others and to Jesus Christ. After having been exposed to different kinds of gifts in the bible, each person tries to relate to one or more gifts and will be discovered. There will be those who relate to prophecy, tongues, administration evangelism, and so forth. It is the same thing when Bryant affirms that "The gift is given not only as a favour from God but also as a means of discovering one's identity and function (ministry) in the body of Christ" (Bryant 1997, p. 157).

\section{CONCLUSION}

It is a true fact that tongues are one of the spiritual gifts provided by God for the spiritual growth of the body of Christ, the church. The gift of tongues has been in existence since the apostolic times to the twenty-first century church. What is more important among all Churches, Roman Catholics, Protestants, Pentecostals, Charismatics, and so forth, is that there is need to re-examine the word of God in its proper interpretation. This is because of the differing opinions, understandings and experiences among the different faiths.

Christians should take into consideration that tongues are biblically evidenced indicating the empowerment of the Holy Spirit for the mission work and Evangelism. Tongues built a valid form directed to God in praise and worship. This calls for

17 | This work is licensed under a Creative Commons Attribution 4.0 International License. 
private and congregational prayer in the church. Therefore, the purpose of the gift of speaking in tongues is for one to worship God and encourage those who do not have the gift to work on the other gifts for the building of the body of Christ. Not all can possess the gift of speaking in tongues. The spiritual life of a person is strengthened in the practice of private prayer in worship. The corporate prayer in the church should remain focused and not be replaced, but be supplemented by speaking in tongues.

The meaning of speaking in tongues is an experience and a sign of the Holy Spirit baptism, but not a criterion for the true faith. The essential evidence of the gift of the Holy Spirit is love because God is Love, not a tongue or a language. The apostle Paul affirms when he says that "If I speak in the tongues of men and of angels, but have not to love, I am only a resounding gong or a clanging cymbal" (1 Cor. 13: 1 NIV). Those who claim that tongues had ceased as the apostle Paul had said, "... where there are tongues, they will be stilled" (Acts 13: 8 NIV), are limited with the meaning of speaking in tongues. The verse brings an eschatological meaning in which at the second coming of Christ, there will be no tongues, apart from love. In heaven, there will be only one language spoken by the perfection of all in the presence of Jesus Christ. It is the working of the Holy Spirit in the life of the believer and he has no fold.

\section{REFERENCES}

Bridge, D. \& Phyphers, D. (1999). Spiritual Gifts, and the Church. Newly Revised and Expanded edition. Great Britain: Christian Focus Publications.

Bryant, C. V. (1997). Rediscovering the Charismata. Building Up the Body of Christ through Spiritual Gifts. Texas: World Books.

Conn, L. (n.d). The Baptism of the Holy Ghost Speaking in Tongues. Retrieved on March 2, 2021 from https://www.eternaltruth.rocks/spiritual-giftsspeaking-in-tongues
Green, M. (2004). I Believe in the Holy Spirit, revised edition. Eastbourne, England: Kingsway Communications Ltd.

Grossman, S. (2008). Charisma. The Gifts of the Spirit. Illinois: Key Publishers Inc.

Grudem, W. (1994). Systematic Theology. An Introduction to Biblical Doctrine. Grand Rapids, MI: Zondervan.

Keener, C. S. 2001. Gift and Giver. The Holy Spirit for Today. Grand Rapids MI: Baker Academic.

Kenneth, K. C. (2009). Gifts of the Spirit. Nashville: Abingdon Press.

Strauss, L. (2004, May 25). Speaking in Tongues. Retrieved on March 2, 2021 from Bible.Org, https://bible.org/article/speaking-tongues

Wagner, C. P. (2007). Your Spiritual Gifts Can Help Your Church Grow. California: Regal Books. 